\title{
Brandenburg's new university feels the pace of change
}

Potsdam. The newly founded University of Potsdam in the east German state of Brandenburg will finally elect its first independent senate by the end of spring, according to a statement issued last week by Brandenburg's ministry of science, research and culture.

The university will have been built virtually from scratch in less than three years. But the pace of the university's establishment has still been criticized as too slow. Delays have created an uncertain working atmosphere for new staff, and stress on temporary staff, who have not yet been told whether they have a future at the university.

After reunification in October 1990, Germany's science advisory council, the Wissenschaftsrat, reviewed the science and higher education infra- University of Potsdam structure in the former

East Germany. In Brandenburg this procedure was complete in the spring of 1991 .

The Wissenschaftsrat recommended the founding of three universities, the largest to be in Potsdam, the state capital, and two others at Cottbus and Frankfurt-Oder. The federal government agreed to pay nearly half of the DM3 billion (US\$1.9 billion) cost of building the new establishments.

The Brandenburg government reacted very quickly, passing the first university act in the new Länder in June 1991. The act anticipates a total of 34,000 student places by the year 2000 . Around 60 per cent of these will go to the three universities, with 10,500 at Potsdam, and 40 per cent to the five newly founded, technologically orientated Fachhochschulen.

Potsdam University is being developed at the site of the Brandenburgische Landeshochschule. This was established in 1948 with the intention of becoming a university. But when East Germany was founded in 1951, the status of the institute was reduced to that of a Pädagogische Hochschule (teacher training college).

After the Berlin Wall came down in October 1988, the Hochschule readopted its original name. At that time it had 120 professors and more than 500 other academic staff. In September 1990 it held its first free elections for a senate, and in July 1991 the college was re-established as a university.

A non-elected temporary founding senate was put in place by the ministry of science. Originally intended to sit for only two years, the founding senate found that the process of setting up the university's structure took much longer than expected. Brandenburg's science minister now says that the first independent senate elections will take place "during the winter semester". But the continuing delays have caused some unhappiness, particularly among the former academic staff of the Hochschule.

Reunification put enormous pressure on these staff. They had to be evaluated for their "personal and political integrity", as well as their professional competence to do their work. The evaluation committees, which consisted of professors from the new and old Länder, and academic and student representatives, completed the task by the beginning of 1992 .

Twenty-five of the 120 professors were sacked for collaboration with the secret police, and a further fifty left of their own accord. The remaining professors were recommended as being suitably qualified to continue their jobs.

Even then, however, there was no immediate peace for them. The founding senate set up a second round of evaluations, this time with more specialist committees. This process is not yet complete. But 30 have so far been positively evaluated, and their positions are waiting for approval by the ministry of science. A further seven have

\section{AIDS foundation plans three centres}

Paris. The opera singer Luciano Pavarotti has pledged part of the proceeds of an openair concert in Paris last month - and those of future concerts - to the AIDS foundation set up earlier this year by Luc Montagnier of the Pasteur Institute and Federico Mayor, director-general of the United Nations Educational Scientific and Cultural Organization (UNESCO).

Donations from Italian banks and individuals have already provided the "World Foundation for Research and Prevention of AIDS" with around US\$650,000. These donations have covered the foundation's start-up costs. They have also covered the first phase of its prevention and social programmes in Africa, including a FF5 million $(\$ 900,000)$ project to educate children whose parents have died of AIDS. not made the grade, and they will either be sacked or offered lower positions.

The fate of more than 500 other nonprofessorial academic staff (the mittelhau) remains uncertain. Around 90 per cent were positively evaluated by the Wissenschaftsrat and put on interim contracts while the new structure was being developed. But the new university will not be able to employ all of them and about a hundred are likely to lose their jobs.

Like all establishments in east Germany, the university has the right until the end of this year to dismiss staff if they are surplus to the requirements of the new structure. But procedures are moving so slowly that this deadline may not be met.

Dismissals after the deadline will be much more complicated because, in the former East Germany, nearly all university academics were on permanent contracts. Unless this is changed before January - the university wants to offer short-term contracts to 80 per cent of the mittel bau it retains - they will be guaranteed a job for life because academic staff are civil servants in the federal republic.

The mittelbau will not be whittled down in all departments. Much of the science faculty, for example, is being built up. The former biology department had five professors and 35 mittelhau; it is now to have 17 professors and will increase other academic positions accordingly. Several entirely new 'interdisciplinary' departments such as nonlinear dynamics and cognition, are being created - an enormous scientific advantage for the university, according to Jürgen Kurths, a chaos researcher.

Potsdam University is keen to establish a good social mix among its professors, and a good spectrum of ages. According to Gerhard Kempter, a chemist and deputy rector of the founding senate, around a quarter are likely to be elected from the new Länder. The rest will be Westerners.

Alison Abbott
The foundation's funds are still far short of the $\$ 30$ million or so it will need to finance three planned clinical research centres. But Pierluigi Vagliani, an adviser to Mayor, says he is confident that income will rise sharply in the new year.

The Saint Joseph Hospital in Paris has provided the foundation with a three-storey building for the first centre. The government of the Ivory Coast has supplied land for a second. And Montagnier is negotiating with an institute in California to build a third, says Vagliani.

Each of the three centres will concentrate on Montagnier's research into cofactors (see Nature 361, 287; 1993). But Vagliani says that the foundation is actively seeking international participation to open other new areas of research.

Declan Butler 